\title{
The Effectiveness of Problem-Based Learning in Improving Students' Writing Descriptive Text in Vocational School
}

\author{
Rindi Dwi Amalia $^{\text {a, }}{ }^{*}$; Rusfandi ${ }^{\text {a, } 2}$ \\ a. English Education Study Program, Faculty of Language and Literature, Universitas Kanjuruhan Malang, \\ Indonesia \\ 1 amaliarindi210@gmail.com ${ }^{*}{ }^{2}$ 0706057601@unikama.ac.id \\ *korespondensi penulis
}

\section{Informasi artikel}

Received :

October 23, 2019.

Revised :

December 12,2019.

Publish :

January 31, 2020.

Kata kunci:

Problem-based

learning

Descriptive text

Vocational school

Keywords:

Problem-based

learning,

Descriptive text,

Vocational school

\begin{abstract}
ABSTRAK
Salah satu kendala yang dihadapi guru dalam mengajar Bahasa Inggris kepada siswa di sekolah menengah kejuruan adalah bagaimana membuat siswa lebih aktif, kreatif, dan kritis. Metode pengajaran alternatif yang dapat digunakan oleh guru untuk mengatasi permasalahan tersebut adalah Problem-Based Learning (PBL). Tujuan dari penelitian ini adalah untuk mengkonfirmasi apakah penggunaan PBL memberikan pengaruh yang signifikan pada kemampuan menulis teks deskriptif siswa dalam Bahasa Inggris. Penelitian ini menggunakan desain quasiexperimental yang dilakukan di sebuah sekolah kejuruan di Malang. Sampel penelitian ini adalah siswa kelas X Administrasi Kantor 1 sebagai kelompok eksperimen yang terdiri dari 23 siswa dan siswa kelas X Administrasi Kantor 3 sebagai kelompok kontrol yang juga terdiri dari 23 siswa. Peneliti memberikan pretest dan post-test dan membandingkan skor menulis siswa di kelompok kontrol dan eksperimen dengan menggunakan independent sample $t$-test. Hasil dari post-test menunjukkan bahwa siswa di kelompok eksperimen memperoleh nilai rata-rata lebih tinggi daripada siswa di kelompok kontrol. Hasil analisis statistik menunjukkan bahwa ada perbedaan skor yang signifikan antara kedua kelompok ( $t$ $=6,99, p<0,05)$. Temuan ini menunjukkan bahwa PBL dapat menjadi metode yang efektif bagi guru dalam mengajar descriptive writing.
\end{abstract}

\begin{abstract}
The Effectiveness of Problem-Based Learning in Improving Students' Writing Descriptive Text in Vocational School. One of the problems in teaching English to students in vocational high schools is how to make the students more active, creative, and critical. An alternative teaching method that can be used by teachers is Problem-Based Learning (PBL). The objective of this study is to investigate whether the use of PBL provides a significant effect on the students' writing descriptive text. This study used a quasi-experimental design which was conducted at a vocational school in Malang. The participants of this study were class X Office Administration 1 as the experimental group consisting of 23 students and class $X$ Office Administration 3 as the control group consisting of 23 students. The researcher gave pre-test and post-test and compared the participants' writing scores in the control and experimental groups by using an independent sample ttest. The result of the post-test indicates that the students in the experimental group achieved a higher mean score than those in the control group on writing descriptive text. The statistical analysis reports that there was a significant difference in scores between the two groups $(\mathrm{t}=6.99, \mathrm{p}<0.05)$. This finding indicates that PBL can be an effective method for teachers in teaching descriptive writing.
\end{abstract}

Copyright (C) 2020 (Rindi Dwi Amalia \& Rusfandi). All Right Reserved

How to Cite: Amalia, R. D., \& Rusfandi (2020). The Effectiveness of Problem-Based Learning in Improving Students' Writing Descriptive Text in Vocational School. Jurnal Inspirasi Pendidikan, 10(1), 1-10.

This work is licensed under a Creative Commons Attribution-ShareAlike 4.0 International License. Allows readers to read, download, copy, distribute, print, search, or link to the full texts of its articles and allow readers to use them for any other lawful purpose. The journal hold the copyright. 


\section{INTRODUCTION}

An effective method for teaching and learning process is required to encourage students to become more active and to have critical thinking in their learning process. One of the effective methods to teach writing descriptive text according to researchers (e.g., Jumariati \& Irawati, 2017; Mundilarto \& Ismoyo, 2017) is Problem-Based Learning (PBL). The use of this method could engage students to be more active and communicative in learning language compared to the relatively more traditional teaching methods such as lecturing, drilling, and memorizing (Jumariati \& Irawati, 2017). PBL basically focuses on students centred-learning which encourages students to do problem solving in certain cases. In PBL, students are given issues and requested to identify what they require to study to solve the issues (Bhale \& Anandgaokar, 2018; Hmelo-Silver, Duncan, \& Chinn, 2007). Although PBL was used for medical field for the first time, nowadays PBL is also used in the fields of education (Elizabeth \& Zulida, 2012).

According to Hmelo-Silver (2004), PBL is "an instructional method in which students learn through facilitated problem solving where the students are as a learning center on a complex problem that does not have a single correct answer" (p.235). She noted that to solve a problem, students need to work in collaborative groups to identify what they need to learn and what they need to know to solve the problem. The role of a teacher in PBL is more as a facilitator and not just as a knowledge provider during the learning process. As a teaching and learning method, PBL has some components which include problem, facilitator, collaboration, and reflection (Hmelo-Silver, 2004). These three components will be discussed in the following sections to obtain clearer understanding about PBL.

The first component is problem. Problems in PBL should be provided in the form of unstructured realistic problems. It means that the problems should allow and encourage students to evaluate their current knowledge, reasoning, and learning strategies. The problems should also enable the students to know and learn. For example, the problems provide realworld problems or experiences around students' daily life. Such problems should help students become engaged in the learning process based on their understanding.

The next component is facilitator. Within PBL, a teacher is a facilitator who functions more as an expert who provides good strategies for learning and thinking, not in the content itself. His or her main responsibility is to move the students through the various stages of PBL and to monitor the learning processes. As a facilitator, the teacher should monitor, make sure that all students are involved in a teaching-learning process, and encourage the students to be active in thinking and responsive or critical on other students' comments or thinking.

The third component is collaboration. In collaboration or group discussions, students try to negotiate ideas and bring new knowledge to the group in an attempt to solve a problem. Hmelo-Silver (2004) argues that small group discussions and debates in PBL increase students' problem-solving skills and higher-order thinking. Collaboration or group discussion also promotes the shared knowledge that students have. In PBL, students often work together to build collaborative solutions (Hmelo-Silver \& Barrows, 2006).

The last component is reflection. Reflection is an important step in PBL because it helps students to relate the new knowledge with their previous understanding before PBL is applied. It also helps students to understand how their learning and problem-solving strategies can be reapplied. Therefore, the use of PBL will improve the students' understanding. In other words, the use of PBL enables students to reflect on how well they collaborate with group discussions, and how effectively they manage or lead their learning (Hmelo-Silver, 2004). 
Savery $(2006,2009)$ mentions three essential characteristics of PBL. Firstly, students must be responsible for their learning. PBL is a student-centered learning that empowers the students to integrate and apply knowledge and skill to develop a solution in resolving a problem. Students are given a problem and they must solve the problem with whatever their current knowledge. Every student has the responsibility to seek the information to get a possible solution.

Secondly, the problems used in PBL should be unstructured which means that the problems are without a single correct solution. The students can use their ideas to find out the solution. In other words, students need to learn using PBL to develop critical thinking skill through problem identification and solution exploration. If the problem is well-structured, students are usually less motivated in the development of the solution and idea.

The last, learning should be integrated from various disciplines or subjects. In the process of self-directed learning, students are essentially problem solvers who try to identify the root of a problem and decide what an appropriate solution is for it. During this process of learning, students should be able to integrate information from all disciplines or subjects that might help improve in understanding and solving certain problems.

One of the advantages of PBL compared to so-called conventional teaching methods is that students are treated as people or professionals who are developing knowledge or abilities through a problem-solving process and collaborative way (Kilroy, 2004). Yew and Goh (2016) mention that students who are taught using PBL are likely to obtain the opportunities to solve issues collaboratively and develop self-directed learning habit through practice and reflection. Regardless of the positive descriptions of PBL above, empirical studies are still needed to confirm the effectiveness of PBL particularly because previous studies were conducted using different methodologies (e.g., qualitative, quantitative, survey), courses (e.g., physics, English), and participants' different levels of education.

Despite some similarities, the present study also differs from some previous studies. For example, it is different from Jumariati and Irawati (2017) in terms of the course or subject investigated. Their study employed senior high school students as participants, but the present study used vocational high school students as participants. The results of the present study could be different from Jumariati and Irawati (2017) because physics and English are different courses. The present study is also different from Jumariati and Irawati (2017) concerning the writing skills of English and the participants' levels of education investigated. Jumariati and Irawati (2017) focused on the use of PBL to improve university-level students' argumentative writing skills, while the present study investigated the effectiveness of PBL in improving vocational school students' descriptive writing skills. These differences in types of writing skills and students' education levels investigated between the present study and the previous studies could result in different findings because university students usually have higher English proficiency levels and relatively better knowledge and experiences of writing compared to vocational high school students.

This research intends to address the research question: 'does the use of PBL provide a significant effect on the students' English descriptive writing ability?' The study hypothesizes that the use of PBL (the treatment given to the participants in the experimental group) provides a significant effect on the students' English descriptive writing ability compared to a relatively more conventional method that is a small group discussion which is the treatment given to the students in the control group. 


\section{METHODS}

In this research, the researchers used a quasi-experimental research design because the researchers determined rather than randomly assigned two classes to be samples (Field, 2009). The first class was class $X$ Office Administration 1 as the experimental group consisting of 23 students and the second class was class X Office Administration 3 as the control group consisting of 23 students. The total number of the students as samples were 46 .

Eight meetings were allocated to collect the data, four meetings for each group. The main instrument of this study was a test. The researchers administered two tests: pre-test and post-test. In the first meeting, the experimental and control groups were given a pre-test by the researchers before receiving the treatment. The purpose was to know and ensure that the participants had a relatively equal ability in writing a descriptive text. After conducting the pre-test, each group was given a different treatment. The students in the experimental group were firstly taught using PBL where the students were given a problem, asked to solve the problem, and then had to write a descriptive text based on the solution they achieved. The students in the control group were taught using a small group discussion as a method where they were divided into some small groups. Each group consisted of 4-5 students. Then, they were given a topic to write a descriptive text. They had to discuss with their group and write a descriptive text based on the topic given by the researchers. The post-test was conducted after the students received the treatment in the last meeting. The purpose was to measure the effectiveness of PBL as a method in teaching descriptive writing.

Each group had three meetings for the treatments. For the experimental group, the researchers gave a brief explanation about the structure of descriptive text in the first meeting of conducting the treatment. Then, the researchers explained what PBL is and how the students could learn descriptive writing using this method. Then, the researchers asked the students to make groups and gave every group a problem. The problem was about a situation faced by a married couple during a hurricane in an ocean. Each group identified, discussed the problem, and should find the solutions. In the second meeting, the students still received the same topic as in the first meeting. The researchers asked each group to write a descriptive text based on the solutions they have discussed before in the previous meeting. After that, each group presented their writing in front of the class to share what ideas they had developed. In the last meeting for the treatment, the researchers gave a review about descriptive text and PBL then gave the students a new topic. The topic itself was about a future dream house. The students were given a problem, asked to find the solution, and requested to write a descriptive text individually.

For the control group, the researchers gave a brief explanation about the structure of descriptive text. Then, the students were asked to make a small group consisted of 4-5 students and discussed the given topic. It was about a situation faced by a married couple during a hurricane in an ocean. After that, each group should write a descriptive text based on the topic. In the second meeting, the students still discussed the same topic as the previous meeting. After that, each group read their writing in front of the class. For the fourth meeting, the researchers gave a short explanation about descriptive text. Then the students were given a topic 'future dream house' and asked to write a descriptive text individually.

To evaluate the students' writing, an adapted version of Brown's (2007) writing performance evaluation was used comprising of five aspects: content (C), organization (O), grammar $(G)$, vocabulary $(V)$, and mechanics $(M)$. The maximum score for each aspect is 4 , and the minimum score is 1 . The maximum overall score is 100 and the minimum overall score is 25 . The overall writing score was computed using the following formula. 


$$
\text { Score }=\frac{30 \mathrm{C}+20 \mathrm{O}+20 \mathrm{G}+15 \mathrm{~V}+15 \mathrm{M} \times 10}{40}
$$

To ensure that the materials and instrument used in the study were valid, the researchers matched them with the 2018/2019 syllabus of English course taught in the vocational school where this study was conducted. In other words, this study implemented content validity by basing the materials and test on the syllabus used in the school. Based on the syllabus, one of the competencies expected after the teaching of English is that the students should be able to write a descriptive text. The explanation about the material for writing descriptive text is in point $3.7,4.8$ and 4.9 of the syllabus. As stated in point 3.7, the students should be able to analyze social function, text structures, and language features of descriptive text relating to persons, tourism places, and historical buildings. According to point 4.8, students should be able to understand the meaning of oral and written descriptive texts. Finally, based on point 4.9, the students should be able to create descriptive texts.

The results of the students' pre-test and post-test were scored by two raters to ensure the reliability of the scores (Multon, 2010; Stemler, 2007). The first rater was the English teacher in the school where this study was conducted, and the second rater was the first researcher. To ease the process of scoring, the two raters used a scoring rubric developed by (Brown, 2007). The correlation of the scores provided by the two raters both for pre-test and post-test were computed using Pearsons Product Moment Correlation. The result of the reliability test for pre-test scores shows that there was a high correlation between the two raters $(\mathrm{r}=.85, p<$ 0.05). This means that the scores provided by the two raters were consistent. The result of the reliability test for post-test scores also demonstrates a high correlation between two raters $(\mathrm{r}=$ $.94, p<0.05)$. This also indicates that the data were reliable, and the two raters were relatively consistent in scoring the students' descriptive texts.

A homogeneity test was carried out using the Levene test to ensure that the participants had a relatively equal writing ability before treatments were provided in the study. The mean score of the pre-test for experimental groups was 60.78 and for the control group was 58.13. Both groups did not have a considerable difference in terms of the mean scores of their pretest. The result of the homogeneity test which had been calculated using the Levene test shows that both groups were homogenous. It can be seen from the significant value of the calculation $(p 0.59>0.05)$. Hence, both groups had a relatively equal ability in writing English descriptive text before the treatments.

Normality tests were carried out using Shapiro-Wilk to determine whether the data collected were normally distributed both for pre-test and post-test. The result of the normality test for pre-test was not significant as indicated by the significant values of the calculations both for the experimental and control groups $(p=0.60$ for the experimental group and $p=$ 0.84 for the control group). These mean that the data for pre-test were normally distributed. The result of the normality test for post-test was also not significant as shown by the significant values of the calculations ( $p=0.23$ for the experimental group and $p=0.08$ for the control group). Both were more than 0.05 , which mean that the data were normally distributed.

\section{FINDING}

Table 1 below describes the mean score of each aspect of descriptive writing evaluated in this study: content $(\mathrm{C})$, organization $(\mathrm{O})$, grammar $(\mathrm{G})$, vocabulary $(\mathrm{V})$, and mechanics (M). 
Jurnal Inspirasi Pendidikan, VOL.10, NO.1, Edisi Januari 2020

The Effectiveness of Problem-Based Learning in Improving Students' Writing Descriptive Text in Vocational School

Rindi Dwi Amalia ${ }^{1}$; Rusfandi ${ }^{2}$

Hal: $1-11$

Table 1. The Mean Score for each Writing Descriptive Text's Aspect of Post-test

\begin{tabular}{lcccccc}
\hline \multirow{2}{*}{ Group } & \multicolumn{9}{c}{ Mean score for each aspect } & Overall \\
\cline { 2 - 6 } & C & O & G & V & M & scores \\
\hline Experimental Group (N=23) & 3.7 & 3.0 & 2.3 & 2.7 & 2.5 & 73.4 \\
Control Group (N=23) & 2.7 & 2.5 & 2.2 & 2.3 & 2.4 & 60.7 \\
\hline
\end{tabular}

From the table above, it is clear that the experimental group outperformed the control group. There is a huge overall score difference for post-test between the two groups of students. The experimental group's writing overall score is higher than the control group's overall score. According to this result, the use of PBL as a teaching method improved the students' descriptive writing scores.

In terms of content, there is a considerable difference between the texts produced by the two groups of students. It seems that the students from the experimental group could develop more ideas and write more creatively for their descriptive texts than the students from the control group. The students in the experimental group seem to write longer than those in the control group.

There is also a difference in terms of organization between the two groups' writing products. The experimental group achieved a higher mean score for the organization aspect compared to those in the control group. The students belonged to the experimental group seems to be able to write descriptive texts more appropriately in terms of paragraph organization and to describe the ideas in the texts according to the topic.

For grammar and mechanic aspects, the mean scores for the two groups were almost similar. It indicates that the treatments provided by the researcher could not provide a significant impact on the students' grammar and mechanic used in their descriptive texts. The mean score for grammar and mechanic are around 2.0 from 4.0 maximum score (see Table 1 above). It indicates that the students in the two groups still have problems in grammar and mechanic.

For the vocabulary aspect, the experimental group achieved a higher mean score than the control group. This result seems to be logical since the students in the experimental group wrote longer and elaborated more ideas in their writing. Therefore, they used more various vocabularies in their descriptive texts compared to those composed by the students in the control group.

As listed in Table 1, the mean score for content (3.7) is the highest among the other aspects of writing evaluated. It indicates that the use of PBL improved the students' ability in developing and organising ideas for the texts. It seems that through the implementation of PBL, the students were able to develop their critical thinking skills. However, it should be noted that the mean score of content aspect in the descriptive writing composed by the students in the control group is also high (2.7), although it is still far behind the mean score achieved by the students in the experimental group. Then, a comparison was made between the pre-test and post-test mean scores for the content aspect of the descriptive texts produced by the students belonged to the control group, and the result was almost similar which is around 2.6. It indicates that there is a minimal improvement after the students in the control group was taught using group discussion as the treatment.

The result of Independent sample $t$-test for pre-test shows that the overall mean score of descriptive texts composed by the students in the experimental group was 60.78 with the standard deviation of 5.17 and 58.13 for the control group with the standard deviation of 4.83. It means that both groups did not have a significant different ability before the treatment 
was provided $(t=1.79, p>0.05)$. In other words, both groups, experimental and control groups, had a relatively similar ability in writing descriptive text before the treatment was provided.

For the post-test, however, the result of Independent sample $t$-test shows that there was a statistically significant difference of overall writing scores between the texts composed by the students in the experimental and control groups $(t=6.99, p<0.05)$. The overall mean score of descriptive texts composed by the students in the experimental group was 73.61 with the standard deviation of 5.26, and the overall mean score of descriptive texts written by those in the control group was 61.00 with the standard deviation of 6.87 . This finding indicates that there was a significant effect of the use of PBL as a teaching method on the students' descriptive writing ability. Accordingly, the result of this statistical computation rejects the null hypothesis (H0) and confirms the alternative hypothesis (Ha).

\section{DISCUSSION}

The result of this study shows that the students who were taught by using PBL as a teaching method could improve their descriptive writing ability more than those who were taught by using small group discussion. In other words, the students who were taught by using PBL had better achievement on descriptive writing than those who were taught by using small group discussion. It indicates that PBL can be used as an effective method for teaching descriptive writing.

As an effective teaching method, PBL enables the students to develop their learning skill especially in learning to write a descriptive text. They can solve a problem to create a text. Additionally, the use of PBL can encourage the students to work in a collaborative way to share their ideas to solve the problem. PBL also makes the students more creative and develop more critical thinking skills through problem-solving and writing practice. It corresponds to what Yew and Goh (2016) said that students get the opportunities to solve issues in a collaborative setting and to form self-directed learning habit through practice (Yew \& Schmidt, 2012).

The followings are writing samples from post-test composed by a student in the control group (APD) and a student in the experimental group (SNR). The writing samples were written as they were from the participants without any grammatical corrections from the researchers.

\section{a. Control group}

\section{My Future Dream House}

I want have house in the city, a fairly spacious house. That house has five bedroom and have kitchen a neat, two bathrooms. Has a bigger chair, has a green page, big gate. Near the gate is post security and relax room for watching television with a family. Has a wall is blue and water pool is wide and has living room is bigger.

b. Experimental group

\section{The Poor Man and Rich Woman}

In 1821, there was a poor man his name is Bagaskara who feel in love with a rich woman, her name is Bintang. In here, Bagaskara like a dirty boys but he have a well attitude. He has flat nose but very tall and strong. His hair is dark and straight. Bintang is like a 
Princess. She is beautiful woman with blonde hair, pointed nose, light skin and wonderful smile.

One day, Bagaskara meet with Bintang in a garden. From here, he fell in love for first sight and wanted to marry the woman. But the woman asked the man to build her a castle and its garden like her dream house. And Bagaskara so speechless with Bintang asked to build the castle and garden like her dream house. Because Bagaskara do not have anything even for everyday it's not enough. But he will try to build castle and garden with his skill.

3 months later, Bintang wanted to saw the castle and garden like her wanted. And Bagaskara with tired face showed that build. He fell so scored if Bintang not like the build and not received his loved. Because the castle it's like simple house with three bedroom, one bathroom very small, one kitchen, one living room and small garden but it's wonderful. Although it's not like Bintang want, she still received Bagaskara. Because Bintang just wanted to show how hard the man tries to get her loved. And then, Bintang and Bagaskara were married.

From the writing samples above, it is clear that student SNR from the experimental group could write longer than student APD from the control group. It seems that student APD could not develop the idea or topic (future dream house) provided by the researchers in her writing. She also could not make the paragraph more creative. Student APD only wrote what her future dream house looked like in a short descriptive text. When a comparison was made between the texts produced by student APD in the pre-test and post-test, the text length was almost similar. In other words, there was no considerable difference between student APD's texts before and after the treatment (small group discussion).

Unlike student APD's descriptive text, student SNR from the experimental group could transfer and develop her idea and wrote the descriptive text creatively. Different from student APD who wrote what future dream house she wanted to have, student SNR wrote about a woman's future dream house. In her writing, student SNR described what the woman's future dream house looked like instead of the student's SNR own house. There was also a description of a man who fell in love with the woman. Student SNR not only developed her idea in describing what house the woman wanted to have, but she also described what the man and the woman looked like based on her own idea.

Student SNR was able to develop her critical thinking. It can be seen from the way how she solved the problem provided based on the topic. The problem itself asked the student to solve how a person could build his/her future dream house, and what the house would look like. With her idea, the student tried to make a solution in creating a story. Then, she developed the story into a descriptive text. Student SNR wrote that the man who had nothing financially tried hard to build a house for the woman whom he loved. Although in the end, the house did not resemble what the woman wanted, student SNR has attempted to describe that the man with his spirit could build a house for the woman. It indicates that the student tried to think about how to solve the problem faced by the man. She tried to think creatively for her descriptive writing.

The use of PBL encourages students to be more active. During the teaching and learning process, every student could give ideas based on his/her opinion. Working collaboratively, the students also shared their ideas on how to solve the problem. Hence, they actively arranged a descriptive text based on their idea. It is because PBL enables the students to become a centre for their learning. It enables students to share and express their ideas freely. It also empowers the students to learn more about writing descriptive text and to apply 
their thought to get a solution to the problem. These correspond to what Savery (2006) said that the essential characteristic of PBL is students-centred learning.

The result of this study generally confirms the result of a study by Mundilarto and Ismoyo (2017). They used PBL in teaching physics for tenth-grade students of senior high school, and the finding showed that the students who were taught by using PBL achieved better scores compared to the students who were not taught by using PBL. The results of the present study and their study indicate that as a teaching method, PBL is a better way to improve students' learning achievement and critical thinking skills. Although physics and English are different courses, the use of PBL enables the students achieve better learning outcomes for the courses. These two findings open the possibility that PBL can be used as an effective teaching method for other courses, although modification or adjustment might be required based on the specific characteristics of each course.

The result of the present study also corresponds to the finding of research by Jumariati and Irawati (2017). They used PBL in argumentative writing course for undergraduate students. They investigated students' perceptions of learning with PBL. The result of their study showed that the students had positive perceptions of using PBL for their argumentative writing course. Although the previous and the present research studied the effectiveness of PBL using different designs (i.e., qualitative vs. quantitative), the results show positive responses from the participants. In addition, the effectiveness of PBL seems to be not restricted on the participants' different levels of education. As mentioned before the study by Jumariati and Irawati (2017) employed university students, but the present study used secondary vocational school students as the participants. However, further research should be done to reconfirm this possibility. In the present research, the students' perceptions of PBL implementation as a teaching method are not measured. Therefore, it is unknown how the students perceived the effectiveness of PBL in their process of learning writing a descriptive text. We do not understand whether the implementation of PBL is helpful and joyful for the students. Hence, future research should address this aspect so that a more comprehensive picture of the effectiveness of PBL can be achieved.

It should be noted, however, that during the implementation of PBL, the researchers also experienced difficulties particularly during the implementation of it for the first time in the classroom. The students never experienced PBL as a teaching method before, so they were still confused about it. For example, the students could not share their ideas because they were given a problem instead of a topic as they usually received from their teacher. Therefore, the researchers suggest that English teachers should explain PBL and the stages of implementing it before starting to use it in the teaching and learning process. The students may never get PBL before, so they may be still confused on how to deal with it. Teachers also should encourage and motivate the students in learning more about English and share their ideas in learning writing a descriptive text. In other words, the teachers should function themselves more as facilitators rather instructors during the teaching and learning process and ensure that the students know how to deal with every step or procedure of the PBL.

\section{CONCLUSION}

In conclusion, the students who were taught by using PBL achieved better scores on their descriptive writing tasks than the students who were taught by using small-group discussion. The finding of this study indicates that PBL enables the students to improve their writing ability and critical thinking skills. In other words, PBL as a teaching method provides a significant effect in improving students' writing ability on descriptive texts and therefore, it can be one of the effective methods to use for teachers in teaching writing a descriptive text. 
Accordingly, the result of this study confirms the alternative hypothesis (H1) and rejects the null hypothesis $(\mathrm{H} 0)$.

Some considerations are needed in interpreting the result of this study. Firstly, a significant improvement of the writing scores attained by the students taught by the PBL is mostly on content and organization aspects. Inconsiderable improvement is identified for the other writing aspects evaluated: vocabulary, grammar, and mechanics. This insignificant improvement for these writing aspects could be because of the relatively limited meetings given by the school in conducting the research. Therefore, future research should add the numbers of meeting in teaching students using PBL so that they get more practice in learning to write, and more comprehensive results about the effectiveness of the PBL can be obtained. Secondly, familiarizing the students with PBL procedures is also essential to do by researchers. As the case happened in the present study, the students may never get experienced with PBL before; therefore, they need to be guided patiently, particularly during the first time they are introduced with the concept and procedures of PBL.

\section{REFERENCES}

Bhale, D. V., \& Anandgaokar, R. (2018). Study of Effect of Problem-Based Learning Conducted in Biochemistry for First Year M.B.B.S Students and Its Relation to University Examination Results. International Journal of Scientific Research, 7(9), 810. doi:10.36106/ijsr

Brown, H. D. (2007). Teaching by Principles: An Interactive Approach to Language Pedagogy (3 ed.). White Plains, New York: Pearson Education.

Elizabeth, M., \& Zulida, A. (2012). Problem-Based Learning: A Source of Learning Opportunities in Undergraduate English for Specific Purposes. The International Journal of Social Sciences, 3(1), 47-56. Retrieved from https://www.tijoss.com/3rd\%20Volume/Elizabeth\%20Anthony.pdf

Field, A. (2009). Discovering Statistics Using SPSS (3 ed.). London: SAGE Publications.

Hmelo-Silver, C. (2004). Problem-Based Learning: What and How Do Students Learn? Educational Psychology Review, 16(3), 235-266. doi:10.1023/B:EDPR.0000034022.16470.f3

Hmelo-Silver, C., \& Barrows, H. S. (2006). Goals and Strategies of a Problem-Based Learning Facilitator. Interdisciplinary Journal of Problem-Based Learning, 1(1), 2139. doi:10.7771/1541-5015.1004

Hmelo-Silver, C., Duncan, R. G., \& Chinn, C. A. (2007). Scaffolding and Achievement in Problem-Based and Inquiry Learning: A Response to Kirschner, Sweller, and Clark (2006). Educational Psychologist, 42(2), 99-107. doi:10.1080/00461520701263368

Jumariati, \& Irawati, E. (2017). Problem-Based Learning in English Writing Classroom: A Study on Students' Perceptions toward Its Impacts. International Journal of English and Education, 6(3), 180-194. Retrieved from http://www.ijee.org/yahoo_site_admin/assets/docs/18_Jumariati.162160324.pdf

Kilroy, D. (2004). Problem Based Learning. Emergency Medicine Journal, 21(4), 411-413. doi:10.1136/emj.2003.012435

Multon, K. D. (2010). Interrater Reliability. In N. J. Salkind (Ed.), Encyclopedia of Research Design (pp. 627-629). Thousand Oaks, California: SAGE Publications.

Mundilarto, \& Ismoyo, H. (2017). Effect of Problem-Based Learning on Improvement Physics Achievement and Critical Thinking of Senior High School Student. Journal of Baltic Science Education, 16(5). Retrieved from https://bit.ly/2sPhGGD 
Savery, J. R. (2006). Overview of Problem-Based Learning: Definition and Distinctions, The Interdisciplinary. The Interdisciplinary Journal of Problem-Based Learning, 1(1), 920. Retrieved from https://bit.ly/33ZO1Yl

Savery, J. R. (2009). Problem-Based Approach to Instruction. In C. M. Reigeluth \& A. A. Carr-Chellman (Eds.), Instructional-Design Theories and Models (Vol. III, pp. 155178). New York: Routledge.

Stemler, S. E. (2007). Interrater Reliability. In N. J. Salkind \& K. Rasmussen (Eds.), Encyclopedia of Measurement and Statistics (pp. 484-486). Thousand Oaks, California: SAGE Publications.

Yew, E. H. J., \& Goh, K. (2016). Problem-Based Learning: An Overview of Its Process and Impact on Learning. Health Professions Education, 2(2), 75-79. doi:10.1016/j.hpe.2016.01.004

Yew, E. H. J., \& Schmidt, H. G. (2012). What Students Learn in Problem-Based Learning: A Process Analysis. Instructional Science, 40(2), 371-395. doi:10.1007/s11251-0119181-6 